\title{
The Sense of Loneliness in The Solitary Reaper*
}

\author{
Guohui Niu1, Xiang Guo² \\ ${ }^{1}$ Foreign Language Department, Baoding University, Baoding, China \\ ${ }^{2}$ Graduate School, Sichuan International Studies University, Chongqing, China \\ Email: 1695979926@qq.com
}

Received 9 February 2015; accepted 1 April 2015; published 3 April 2015

Copyright (C) 2015 by authors and Scientific Research Publishing Inc.

This work is licensed under the Creative Commons Attribution International License (CC BY).

http://creativecommons.org/licenses/by/4.0/

(c) (i) Open Access

\begin{abstract}
The Solitary Reaper is one of William Wordsworth's representatives which portrays an Irish girl working and singing solitarily in a field. This poem fully reflects the loneliness of the poet. He uses varying wording and phrasing, the lonely image of the reaper, the expanding of the lonely music, and the way of expressing his loneliness to set the lonely atmosphere. Therefore, it is necessary to thoroughly illustrate the diction and rhetoric devices which help to convey the sense of loneliness of the poet.
\end{abstract}

\section{Keywords}

William Wordsworth, Loneliness, The Solitary Reaper

\section{Introduction}

William Wordsworth (7 April 1770-23 April 1850) was an English romantic poet who, with Samuel Taylor Coleridge, helped to launch the Romantic Age in English literature with Lyrical Ballads in 1798. He was one of "lake poets" of his age and a representative poet of the early romanticism. As for the romantic theory and principles, he held that “all good poetry is the spontaneous overflow of powerful feeling” (Bialostosky, 1992).

The Solitary Reaper typically shows the sense of loneliness which is also permeated in many of his other works. The words of the reaper's song are incomprehensible to the poet, so he is free to focus on the tone and speculate the content. The song generates in him a feeling of resonance.

Many scholars have analyzed The Solitary Reaper from the perspectives of romantic poetic writing rules, stylistic aspect, the poet's ecological view, and view on nature. However, this thesis takes the sense of loneliness of

\footnotetext{
*The main character of the poem is The Solitary Reaper, who is cutting and binding grains all by herself and singing alone in a field. Thus, the characterization of this solitary reaper is of great significance. The loneliness of the reaper is to be analyzed in various perspectives.
} 
the poet as the highlight of this poem. It can be found in every nook and corner in The Solitary Reaper. Thus it helps readers to have a better understanding to his poetry and the beauty of this loneliness.

\section{The Presentation of the Lonely Reaper}

\subsection{Wording and Phrasing}

Firstly, the title of poem, The Solitary Reaper, directly and obviously expresses the theme of loneliness. Then, the poet used different words to repeat the reaper's loneliness and emphasized the isolation, such as "single" in "single in the field", "solitary" in "Yon solitary highland lass", "alone" in "Alone she cuts and binds the grain". "Solitary" is defined in the dictionary as one is willing to spend a lot of time alone, which denotes that the reaper loves working on the field by herself and the life of tranquility as well as her communication with nature. Thus, one can also see the poet's passion for nature and yearn for the idyllically rural life, and one's soul can only be lifted and purified by a kind of life. Besides, there are also some words like "by herself", "melancholy", "profound", and "silence", which indirectly creates a sense of seclusion and tranquility, for in this kind of surroundings one can more easily feel lonely and solitary. Moreover, these tautological utterances of "lonely" words which are employed by the poet overwhelmingly stress the lonely image of this reaper and set off a mood of loneliness. The whole poem is based on the atmosphere of lonely background.

The first stanza uses many imperative sentences. For example, the beginning sentence "Behold her, single in the field!" strengthens the visual impact, and put the heroine of the poem into a profound highland field, which foils the loneliness of the reaper. And "O listen!" attracts readers' attention of hearing and forms the lonely image of the maiden with the above-mentioned visual impact. Then "stop here, or gently pass" shows that the poet is afraid of bothering the singing reaper and wishes to keep the harmonious moment. Meanwhile, what is worthy of readers' attention is that the poet put the adjective "Alone" in the beginning of the fifth sentence, strongly stressed the loneliness of the maiden.

Firstly, this poem is the poet's later recollection in tranquility, yet he used the present tense to take the place of the past tense. That makes one feel that he was there at that moment and saw that beautiful picture in his own eyes. Secondly, "To the degree that the shift from the present-tense imperatives of the first stanza of The Solitary Reaper ('Behold...Stop...listen!') To the past tense of the last has been seen as the paradigm of 'emotion recollected in Tranquility', the sitting of the poet affects our entire sense of Wordsworth's poetry" (Manning, 1990). Moreover, the present tense shows the poet's deep impression of that scene, and his wish for its permanence. Thus, the picture of the lonely maiden reaping and singing alone in a field comes to be extraordinarily vivid and impressive.

\subsection{The Lonely Images}

The poet used expressive images to foil the reaper's singing and created an atmosphere of loneliness. They span the widest extremes possible, from the nightingale in the Arabian Desert to the cuckoo-bird in the Hebrides off the coast of Scotland. This abrupt and bold zoom of the perspective creates a lonely mood skillfully. These images also contain deep meanings.

The image of vale contains rich spiritual meaning and it is the home of soul.

Vale, compared with worldly fickleness and fury, is a rather secluded, appealing and tranquil place to lift one's soul and spirit. It indicates nature, a peaceful and consolable life environment. As many other men of letters all over the world, Wordsworth used special images. Here in this poem, "the Vale profound/Is overflowing with the sound". The reaper's voice is so enchanting that the whole valley seems to reverberate with it, which renders it more intangible, distant and lonely. This single reaper, set against a profound vale, looks even lonelier.

The poet compared it to that of the nightingale and cuckoo, whose sounds brought him unspeakable happiness and made him forget the worldly loses and gains.

These two images betray the melancholy and pleasant sound of the lonely reaper. In the poet's view, it is more melodious and enjoyable than that of the nightingale singing to the weary hands in the Arabian deserts or the cuckoo-bird breaking the silence of the seas in the farthest Hebrides. Cuckoo bird's voice is so attractive that it can break the silence of the sea in spring, yet it is still not more desirable than the maiden's singing. "So the song the speaker hears is both welcoming and as familiar as the song of a nightingale, but stands out dramatically in its environment in the same way that a cuckoo's song 'breaks' the 'silence' of the sea. Comparing the 
singer to a bird is another way of emphasizing the harmony of her human activity with the natural world" (Driver, 2001).

When Listening to the reaper's singing, the poet imagined freely and randomly the sound of nightingale and cuckoo bird in a distant desert and a profound sea. These images estrange the picture he described, and creates new surroundings for readers to imagine. On one hand, these images foil the loneliness of the reaper, and on the other hand, expand her loneliness to an infinite, exotic and historical dimension and show that the maiden's singing is omnipresent in nature.

\subsection{The Lonely Reaper in the Nature}

Wordsworth himself is passionate to nature. He encouraged people to go back to nature. Matthew Arnold, in his own preface to a carefully sifted anthology of William Wordsworth's poetry, proposed that:

Wordsworth's poetry, when he is at his best, is inevitable, as inevitable as Nature herself. It might seem that Nature not only gave him the matter for his poem, but wrote his poem for him (Gill, 2003).

Nature is an important element of his poem, and the ordinary people are where his attention lies. Thus, his works are mainly about the ordinary people, namely beggars, children, or maidens, nature, rural or secluded places which are far away from city centers. He believed that in rural conditions, men's elementary feelings find a better soil than in town life and could be better cultivated and strengthened in constant association with nature. So, he advocated that people should get close to nature, love natural life, and keep harmony with nature.

\section{The Expanding of the Lonely Music}

The music is a clue that runs through the whole poem. It exists in every corner and nook of the poem. The lonely music is the soul of the reaper, and the soul of the poem. It is the music that moves the poet, slows down his step, arouses the speculation of the poet and gives him as well as the reader infinite consolation.

\subsection{The Repeat of the Music}

The whole vale is full of the intangible and ethereal music. The first stanza focuses on a lonely highland girl reaping and singing alone and her lonely and sad voice echoes and echoes the bottomless vale. The poet describes the open and wide field, high and clear sky to foil the sorrowful and lonely music. In the second stanza, the nightingale sings out sweeter tune to a lonely visitor in the Arabian Desert; the cuckoo bird sings such a melodic sound in spring time to break the calmness of the oceans among the farthest Hebrides. Yet the girl's singing runs like water and surpasses the beauty of two famous English song-birds, the nightingale and the cuckoo. The poet uses the coldness of Hebrides and darkness of oceans to foil the sad and lonely music. In the third stanza, the poet speculates what the girl is singing for his not knowing her language. He thinks it must be some sad things, some natural sorrow, loss, or pain. The last stanza describes the poet immersing in her singing, motionless and still. Though he has gone far, he still bores that music in his heart. The music gives him infinite consolation and resonance. This unspeakable happiness makes him forget the sorrow of the worldly society.

\subsection{The Symbolic Meaning of the Music}

The music contains a kind of sanity. The maiden's singing is not a masterpiece, nor being performed in the golden hall of Vienna. It is nothing but an ordinary daily lyric sang by a lonely reaper, which does not seem like containing some profound philosophy. However, her singing gives the tune a new meaning, which "pours into" the passenger's mind, and the sound contains every mood of the reaper. The Gods befall due to the maiden's singing. They bless their people, especially the tough labors. When "I" hear the song, "I" receive her selfless gift and share the deity. The accomplishment of the gift is actually the accomplishment of the singing's mission. Then what is the gift? It is brought by her singing, may be some old, unhappy, far-off things, battles long ago, familiar matter of today, or some natural sorrow, loss or pain. In short, "I" think it expresses some suffering, frustration, sadness or loneliness.

\subsection{The Consolation of the Music}

The music gives the poet enormous consolation. Listening to her singing, "I" am immersed in it, which is inno- 
cent, pure and natural, and thinking the life of the maiden. Listening her singing and watching her working in the nature, "I" feel her voice so attractive and even more appealing than that of nightingale and cuckoo bird. "I" feel more than comfort and consolable. The poet's piety to the God or some saint is awakened by her singing so that he can meditate quietly his genuine look and authenticity.

Because of the deity the music contains, the poet feels it more desirable than that of the nightingale and cuckoo bird. In the eye of Romanists like Wordsworth, nature is permeated with deity and everything in the nature is ethereal and sacred. In this sparsely populated field, "I", the passenger, am peaceful and solitude, and am able to envelop everything into his heart in a state of disinterest. In this state of aesthetics, the reaper's singing is like the voice of nature, overflowing in the field, in the vale. "I" am fascinated by her voice, share the deity, and get consolation from nature and the sacred. Different people may have different feelings listening to the same song. With his peculiar life experience, Wordsworth felt eternal consolation and infinite comfort, and the poem, The Solitary Reaper may arouse different feelings in terms of different readers too. The song contains something like the religious worship to some Gods and enlightenment to some degrees, solves spiritual crisis, helps one to find an outlet of negative mood and purifies and lifts one's soul.

\section{The Resonance of the Lonely Passenger}

Loneliness gives one a sense of respect for listening to others. In The Solitary Reaper, onlookers "I" act as a role of a listener, enjoying the maiden's reaping and singing in distance. Besides, in the poetry, "I" either stop listening or walk away quietly. "I am" unwilling to invade her world, nor interrupt her work. The poet can not understand her language, but the plaintive numbers seems to relate the tale of some far off happening or "some natural, loss or pain/That has been, and may be again". The poet is using his own mood to guess that of the reaper, which betrays his sense of loneliness. In this respect, he finds relief in her voice results from his own condition, not her intent. Whatever the song is about, he stands spellbound and carries the music with him till long after it is heard no more. Her singing provides a beautiful emotional experience to the poet. Listening to the touchable melody, he is moved by his own feeling, by the reaper's life condition, ponder her fate and his own fate, and resonate with the reaper. They are united as one in this melancholy lay.

\subsection{The Poetic Theory of the Poet}

Loneliness and melancholy has close relation. Melancholy is some mood, and it is accompanied with loneliness. Wordsworth's loneliness is not to strengthen the melancholy of heart, but it is such like what he said that his poem is to consolate people's sufferings. Therefore, being alone can let people ponder quietly, get rid of melancholy, and enter a state of meditation. In this way, being alone is also the effective way to shake off depression. Just like Rousseau, who is meditating in loneliness to get the philosophy of life, the poet advocates this kind of positive loneliness, that is, to let the beggar and the hobos move towards the nature. Although in the nature they also feel lonely, their suffering from the society obtains the purification from nature. Therefore, loneliness in poetry actually has multi meanings, which is his loneliness's unique charm.

\subsection{The Root of the Lonely Sense}

The lonely sense of the poet has a deep root, including time factor, and personal factors. The time factor includes the rising power of the middle class, the war between British and France and the France revolution, while the personal factor contains his individualistic disposition, the death of his family members and peer pressure. All of these factors lead to his sense of loneliness.

Wordsworth's sense of loneliness has its special reasons. Firstly, during the industrial revolution, the poet went through the deterioration of class and rural gentry system, which is the root of the poet's peace and safety. However, with the emergence and rising of new stratum, the capitalist is becoming increasingly stronger, which makes the suffering and hatred of the mass labors grow with each passing day. The utopia highly was praised by Wordsworth, where the men plough and the women weave in harmony, had already gone. The huge shocks brought by the industry to the agriculture unfold the cruelest and greed facet of human beings, estrange and twist their personality. The massive reformation of social mode of production changed his familiar life style and environment. As a member of the traditional landlord class, Wordsworth was afraid of the threat brought by the uprising middle class, yet he could do nothing to change the trend of history advancement. The familiar produc- 
tion and life style is deteriorating, and facing the strange social surroundings, the poet cannot help feeling lonely.

Secondly, Wordsworth also underwent the war between British and France, and the France revolution. France revolution inspired the poet for a while. However when he saw the pursuit of democracy, freedom and equality evolved into bloody slaughters and chaotic riots, his attitudes turned upside down. In the Prelude, Wordsworth portrays the crisis as "soul's new low, the lowest time" (Mason, 2010), which led to his "emotional desperation". Before long, British formed the anti-French League with other European countries. When the poet saw the motherland declared war on revolutionary ideals he agreed, he had tremendous contradictions inside, and therefore had a moral and emotional conflict and shocking. In pain, Wordsworth turned to Ge Dewen, but quickly abandoned this way.

Wordsworth gradually moved away from earlier support for revolution to take a cautious attitude to the revolution, and advocated a more mild improvement. He hoped that on the basis of the existing system, measures such as improving people's living standards, popularizing education to be taken. When confronting these changes, the poet is not looking into the future, but be a cult of the old social system, laying his hope on the Anglicanism, and the Tory Squires system. His conservative ideas was also questioned and attacked by socially activist. This spiritual crisis as well as the misunderstanding from people generates in him a sense of loneliness. Just as Shelley put it, a poet has a close relationship with his time, in which various changes deeply affected Wordsworth, and gave birth to the poet's sense of loneliness.

Wordsworth had the individualistic disposition. When being young, the poet was rebellious. The poet disdained to collaborate with the reprobate, often skipped classes, only chose the subject he likes, and finally absented from the university graduation test. Therefore he did not get the diploma. As the poet marched into the middle age, under the pressure of supporting his family, he came to hold a conservative point of view, maintained the benefit of the Trolley party and the English rural gentry. Thus, Wordsworth encountered young people's criticism and attack. Judging from this, poet's individuality as well as the change of political position also continuously makes him to be at a kind of edge condition. This is the personal reason of his being lonely. At the same time, the death of his family members in succession, especially the younger brother John, second son, second daughter and younger sister Dorothy, made the situation even worse. Wordsworth also had a dispute with his good friend Coleridge, in addition to the unceasing exterior criticism, which deepened Wordsworth's loneliness.

As the poet laureate, Wordsworth's huge prestige is by no means comes easily for he had experienced many criticism and attack for a lone time.

Wordsworth made the huge reform regarding to the poetry form and the content. He took in the daily life experience as the material of his poetry, which seemed like a kind of subversion to tradition and an innovation in the eye of later generations. However, the present generation regards it as going against with the mainstream, namely the rational style of 18th century. Therefore the poetry anthology is not welcome. Wordsworth's good friend Robert Southey once commented that colloquial style was not suitable for poetry writing, moreover, the theme of the poetry is so ordinary that it is unable to attract the reader. The publisher saw this commentary, and immediately decided to stop the release of poetry anthology. In 1807, Poems, in Two Volumes are published, in which contains Wordsworth's excellent works like The Solitary Reaper, Daffodils, Narcissus flower and so on. But this poetry anthology also not got rid of the misfortune. He was criticized by Walter Scott, Byron, and Francis Zeffrey, the famous poets. His painstakingly work only gave him more criticism. What a depressed thing it was! Therefore, attacks from many aspects together develop his sense of loneliness. This kind of loneliness not only brings to the poet sufferings, but also makes who he is today, a pioneer of poetry writing of new style.

\subsection{The Humanistic Concern of the Poet}

Wordsworth was by no means the poet who fled from the world and lived in seclusion. He cared about the national politics, and also paid attention to the men from the bottom of society. He used own poetry recording that society, as if a mirror showing people's living condition generally. In the context of such a society, there had been a lot of people in abject poverty, beggars and tramps. Wordsworth revealed the roots of their loneliness, and called for help from society to give these people the humane care and humanitarian aid.

Loneliness is a melancholy mood, and the loneliness of these poor people described by Wordsworth is even more profound than others. In the society of that time, their lives are too difficult to face and they are unable to 
change it. Wordsworth gives voice to them and cares their sufferings. Wordsworth's loneliness stretches its root into the loneliness of the general mass.

The Solitary Reaper betrays a sense of loneliness of the poet from (the aspects of) wording and phrasing, lonely images, the portrayal of this lonely reaper and the expanding lonely music. The poet feels this loneliness and writes about it. The loneliness has deep root including both time factor and personal factor. It also influences Wordsworth's poetic theory. As a poet against tradition, Wordsworth abandons the emptiness of classism, and describes simple and ordinary things, which brings people back to genuine life, and enlightens people with sublime philosophy.

Wordsworth's loneliness, as a condition and state of thinking, lets him lift the natural mood into artistic emotion, then unites the real world and the fairyland, and expands the limited material into an infinite world. That is, "Wordsworth records in The Solitary Reaper his reaction to an ordinary incident" (Manning, 1990). He turns his lonely sense into artistic work, and makes his loneliness immortal. Just as William Shakespeare puts it, so long lives this, and this gives life to thee. The Solitary Reaper emancipates people from alienation, and lets them returning to real life, and feeling the coexistence of God and the people. The Solitary Reaper is not only the poet's Muse, but also the angel leading people out of trouble.

Wordsworth's loneliness has great practical significant to modern people. In the modern society, which is filled with noises, depression and fury, seeking for loneliness is particularly eager and crucial. Listening to Wordsworth's lonely soul, as well as listening to the sound of one's own heart, and facing the world calmly are the essence of Wordsworth's philosophy of loneliness.

\section{References}

Bialostosky, D. H. (1992). Wordsworth, Dialogics and the Practice of Criticism. Cambridge: Cambridge University Press. Driver, E. (2001). The Poetry of William Wordsworth and an Imaginary Life by David Malouf. Glebe, N.S.W.: Pascal Press.

Gill, S. (2003). The Cambridge Companion to Wordsworth. Cambridge: Cambridge University Press. http://dx.doi.org/10.1017/CCOL0521641160

Manning, P. J. (1990). Reading Romantics: Texts and Contexts. New York: Oxford University Press.

Mason, E. (2010). The Cambridge Introduction to William Wordsworth. New York: Cambridge University Press. http://dx.doi.org/10.1017/CBO9780511781940 